International Journal of Linguistics, Literature and Translation

ISSN: 2617-0299 (Online); ISSN: 2708-0099 (Print)

DOI: $10.32996 / \mathrm{ijllt}$

Journal Homepage: www.al-kindipublisher.com/index.php/ijllt

\title{
Customization and Contextual Teaching Approach Efficiency in Promoting English Proficiency among Saudi EFL Learners
}

\author{
Dr. Elsadig Ali Elsadig Elandeef 18 (D) and Dr. Ayman Hamad Elneil Hamdan 28 (D) \\ ${ }^{12}$ Assistant Professor, English Department, King Khalid University, College of Sciences \& Arts, Dhahran Aljanoub, Saudi Arabia \\ $\triangle$ Corresponding Author: Dr. Ayman Hamad Elneil Hamdan, E-mail: aabdala@kku.edu.sa
}

ARTICLE INFORMATION ABSTRACT

Received: February 17, 2021

Accepted: March 14, 2021

Volume: 4

Issue: 3

DOI: $10.32996 /$ ijllt.2021.4.3.15

\section{KEYWORDS}

Customization, contextual teaching approach, differentiation, individualization, personification
This study investigated the proper implementation of customization and contextual teaching approach in fostering English proficiency among King Khalid University's students studying English as an intensive course. The study aims to implement customization and contextual teaching approach in teaching the English language as an intensive course at King Khalid University and inculcate the tendency to activate updated teaching approaches to assimilate Saudi learners' attention in English class. To achieve the aim of the study, the researcher employed the descriptive analytic method. The subjects of the study consisted of $50 \mathrm{EFL}$ teachers drawn from King Khalid University. The study showed that customization and contextual teaching approach grasp Saudi students' attention, satisfy their needs and preferences, and consider their learning styles. Moreover, the study has concluded that the students' needs, preferences, and learning styles are the milestone of the learning process's success. The study concluded that consideration of students' needs, preferences, learning styles and correlating them to social life setting play a crucial role in facilitating learning the English language.

\section{Introduction}

Learning English as a foreign language is based on three pillars: input, context and output. The input involves language exposures from different perspectives, whereas output entails English production in speaking, writing, and comprehension. Context refers to language in a communicative situation which is based on authenticity and non-authenticity (David Crystal, 2001). Furthermore, learning English as a foreign language involves linguistics, social, psychological, and pedagogical consideration, facilitating and accelerating the learning process. As one of the economic pioneers' countries owning a peculiar position globally, Saudi Arabia set a strategic objective concerning learning English as a fundamental means of global communication from a continuous development perspective. As a result, the preparatory year programs have been set in different Saudi universities, the classroom has been equipped with tools and devices to enhance the teaching and learning English language and professional English teachers have been recruited in different Saudi universities. In Saudi Arabia, particularly at King Khalid University, pedagogy, curricula, and assessment can hardly embrace individual difference, learners' needs and preferences, and learning styles. Moreover, foreign language aptitude is not considered in teaching English as a foreign language at King Khalid University program such as English Intensive Course. Foreign language aptitude (FLA) refers to the potential that a person has for learning languages, and it is a relatively stable talent for learning a foreign language that differs between individuals. (Dörnyei and Skehan 2003). Carroll's (1962) subsequent conception of FLA comprised four components: phonemic coding ability (i.e. the ability to identify and retain sounds and link them to phonetic symbols); sensitivity towards the grammatical functions that words fulfill in a sentence; the ability to learn inductively (i.e. to infer and generalize linguistic structures from language samples); and the ability to rote learn vocabulary items paired with their associated translations.

K C AL-KINDI CENTER

$\mathbf{R}$ D FOR RESEARCH AND DEVELOPMENT

Your gateway to world-class research

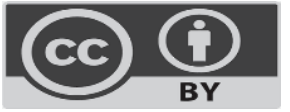

Published by Al-Kindi Center for Research and Development. Copyright (c) the author(s). This open access article is distributed under a Creative Commons Attribution (CC-BY) 4.0 license

The authors extend their appreciation to the Deanship of Scientific Research at King Khalid University for funding this work through General Research Project under grant number (project number: 76 /year: 2021)". 
This study investigates the proper implementation of customization and contextual teaching approach in fostering English proficiency among King Khalid University's students studying English as an intensive course. Customization is firmly linked to how learners' needs are met, so each learner finds nearly exactly what they want. Customized instruction satisfies the demands for learners' satisfaction. Customized learning seeks to gear classroom content, instruction, and other learning aspects towards individual students, their unique interests, and past learning experiences (Hattie, 2009). Customized learning involves differentiation, individualization and personification strategies. Individualization refers to the set of didactic strategies aiming to guarantee all students' mastery of the same learning objectives by adjusting the pace to the learner's progression. Personalized learning refers to the learning that is tailored to various learners' preferences and interests and instruction that is paced to a student's unique needs (Gee,2007). A Contextual teaching approach involves active students in the learning process to find the concepts learned by linking the material with the knowledge possessed and the student experience in daily life. It provokes students actively to be able to connect the content of the material they have learnt to the context of their daily life, so When students to connecting the English language with real-life practice, then they can connect grammatical concepts to their language production in a real-life setting.

\subsection{Statement of the Problem}

Most of the students studying English as an intensive English course at King Khalid University are exposed to different hinders in learning English as a foreign language. These obstacles entail a lack of consideration of social, psychological, learning, learning style, foreign language aptitude, and individual differences. As a result, learning English becomes a problematic issue, and the learners tend to be exam-oriented. Furthermore, faulty textbooks selection, faulty teaching methods used in English class and lack of satisfying learners' needs lead to frustration and developing English class avoidance strategies. Hence, it is crucial to solve such a problem by considering customization, individualization, personification and differentiation in teaching and authentic textbook selection.

\subsection{Aims of the Study}

The general aims of this study are:

1- To implement customization and Contextual Teaching approach in teaching English language as an intensive course.

2- To implement the modern linguistics and pedagogic theories in teaching English language, focusing on foreign language aptitude in teaching and textbook selection to make learning English much easier among students.

3-To inculcate the love of learning English among the Saudi learners and create a sense of engagement and social belonging in English class via creating a sense of engagement and social belonging in English class by minimizing difficulties faced by authentic reading and listening textbooks.

4. To inculcate the tendency to activate updated teaching approaches such as task-based teaching and test-based teaching approaches to assimilate Saudi learners' attention in English class.

\subsection{Questions of the Study}

The study seeks to find answers to the following questions:

1- How does the lack of customization in the teaching process make learning English difficult?

2. To what extent does the implementation of the contextual teaching approach in teaching English as an intensive course program foster learning English?

3. How do contextual teaching approach and customization assimilate Saudi learners' attention in English class?

\subsection{Hypotheses of the Study}

1- The lack of customization in the teaching process makes learning English much more difficult.

2. Implementation of contextual teaching approach in teaching English as an intensive course program fosters learning English.

3. Contextual teaching approach and customization assimilate Saudi learners' attention in English class.

\subsection{Significance of the Study}

1- The findings of this study will hopefully help English teachers consider customization, individualization, personification and differentiation in the teaching process and authentic textbook selection.

2-It will accentuate the importance of social, psychological, individual and Saudi life factors in designing English syllabus and teaching processes. 
3-It will shed light on contextual teaching approach from the Saudi continuous development strategy perspective.

4-It will highlight the importance of individual differences, foreign language aptitude and Saudi learners' needs in the textbook selection process

\subsection{Research Methodology}

The research data collection instrument was a questionnaire consisting of 16 items. The subjects were chosen purposively from King Khalid University English language teachers teaching English as an intensive course. The researcher conducted a pilot survey and used statistical techniques to verify the questionnaire's validity and reliability. The overall research method used was the descriptive-analytic method.

\subsection{Delimitation of the Study}

The study was conducted at King Khalid University in Abha, KSA, in 2021. The instructors are of different nationalities working as English instructors for KKU.

\section{Review of literature}

\subsection{Customization}

Customization involves differentiation, individualization and personification strategies. Differentiation is a type of learning where instruction is tailored to meet individual students' learning needs, preferences, and goals. In other words, in the differentiated instruction model, the teacher adapts instruction to meet the needs of different groups of students (Martinez, 1999). According to the U.S. Department of Education, "Learning goals are the same for all students, but the method or approach of instruction varies according to the preferences of each student or what research has found works best for students like them." ${ }^{3}$ Differentiated instruction involves the teacher adapting various classroom elements according to their students' needs. According to the U.S. Department of Education, "Personalization refers to instruction that is paced to learning needs, tailored to learning preferences, and tailored to the specific interests of different learners. In a fully personalized environment, the learning objectives and content, as well as the method and pace, may all vary." From this definition, we can see some overlap between differentiation and personalization as they both involve catering instruction to different learning needs (Pipkin, 2015). The main difference between personalized learning and differentiated instruction is personalization's focus on the student's agency in designing their own learning path depending on their interests and style. In contrast, differentiation focuses on the teacher adapting their lessons to different learning types and accounting for the various students in the room (Zmuda, Ullman, \& Curtis, 2015).

Individualized learning entails instruction calibrated to meet the unique pace of various students. In practice, it describes students working through set materials or curricula at their own rates. With individualized instruction, learning strategies are based on student readiness, interests and best practices. Unlike individualized instruction, ${ }^{4}$ personalized learning involves the student creating learning activities and relies more heavily on a student's interests and innate curiosity. Instead of education being something that happens to the learner, it occurs due to what the student is doing to create engaged students who have truly learned how to learn (Tseng \& Jiao, 2001).

\footnotetext{
${ }^{3}$ There are two approaches to practicing Differentiation: Intuitive and Intentional. When used together, the effective and efficient practice of personalization and individualization of instruction can take place. Intuitive differentiation occurs 'in the moment' as instruction happens. Teachers make adjustments based on "how students respond - or do not react - to the plan (John McCarthy, So All Can Learn: A Practical Guide to Differentiation). A core skill of teachers is being able to adapt instruction when some students appear to be lost, or for learners who find the work to be not challenging. Intentional differentiation happens during the lesson planning process. Preplanning enables teachers "reflecting on and implementing the elements of differentiation into lessons provides strategic support of student learning" (John McCarthy, 2017). If we know that students are likely to negatively struggle with an upcoming lesson, or have previously learned the targeted skills, then preplanning differentiation based on assessment data is necessary for greater chances of learner success.
}

\footnotetext{
${ }^{4}$ 2- The learning experiences may be differentiated in several ways: Whole-Class

The teacher provides a variety of graphic organizers and other tools to students based on their needs while conducting a whole class experience. The lesson might also include jigsaws or think-pair-shares that encourage students to support each other's thinking during the whole class lesson.

Small Groups \& Individuals

The teacher plans centers activities where students rotate between stations that include folders, each assigned to the needs of student groups. The centers could also be virtual to add more options and address any room space challenges. The teacher has the option to move around to provide help where needed or run a station to meet with groups or individuals for coaching support.

Choice-based

The teacher designs and offers set choices. The students pick from the options, giving them some control of their learning experience. Choice is a gateway to true student voice, which is often fostered through personalized learning.
} 
Powell and Kusuma-Powell (2011) stated that differentiated learning is instruction tailored to different students' learning needs and preferences. It includes the modification of four curriculum-related elements which are based on three categories of student need and variance-readiness (how currently equipped a student is for learning specified content), interest, and learning profile (a student's preference for what is learned, how it is learned, and how it is expressed):

-Content-what knowledge and skills do students need to learn

-Process-how students learn or understand the content

-Product-how students demonstrate their understanding

-Affect-how students' disposition impacts learning

${ }^{5}$ Personalized learning is defined as tailoring learning for each student's strengths, needs, and interests-including enabling student voice and choice in what, how, when, and where they learn-to provide flexibility and support to ensure mastery of the highest standards possible (Zmuda, Ullman, \& Curtis, 2015). Bray \& McClaskey (2015) identified 10 essential components of personalization. They are:

- Student agency

-Differentiated instruction

-On-demand and immediate instructional interventions and support for each student

-Flexible pacing

-Individual student profiles or learning paths

-Deeper learning and problem solving

-Frequent feedback from both instructors and peers

-Standards-based knowledge and skills

-Anywhere, anytime learning

-Performance-based assessments

In a ${ }^{6}$ personalized learning classroom, students and teachers co-design their objectives and learning based on their learning goals, meaning each student drives and owns their unique learning journey. Student critical thinking is encouraged, and they are tasked with choosing and using the appropriate resources and technological tools necessary for their learning. Martinez (1999) contended that individualized learning refers to learning experiences in which the pace of learning is adjusted to meet individual students' needs. In other words, individualized learning focuses on the question of when students receive a learning activity.

All students go through the same experience in individualised learning, but they move on at their own individual pace. Individualized learning is a critical element of personalized learning. ${ }^{7}$ Individualizing learning involves three elements of the

\footnotetext{
${ }^{5}$ Personalizing is actively including the learner in constructing their understanding. What skills and life experiences does she have, and how could they be used to tackle concepts and skills? What the student brings is used along with academic assessment data to craft learning experiences that use the student's strengths and interests. For example, let students design their homework practices and assessments, with guidance on the academic criteria from the teacher. An easy first step is to give students two options as designed by the teacher. Then, give them a third option, which is to develop their own idea. The teacher listens to the student's proposal. The design can be accepted, revised, or sent back to students for developing a new idea. If the student does not get a proposal accepted within a specified time frame, he must pick from the teacher-designed options.
}

\begin{abstract}
${ }^{6}$ Rock, Gregg, Ellis, and Gable (2008) explained the theoretical framework of differentiated instruction, based on Tomlinson's work, through four guiding principles and seven essential beliefs. The four guiding principals include (a) A focus on essential ideas and skills in each content area, (b) responsiveness to individual student differences, (c) integration of assessment and instruction, and (d) ongoing adjustment of content, process, and products to meet the individual students' levels of prior knowledge, critical thinking, and expression styles. Furthermore, Rock et al. (2008) described seven essential beliefs about differentiated instruction, again based on Tomlinson's work, which include (a) experiences in life and readiness to 10 LANDRUM \& MCDUFFIE learn differ significantly among same-aged students; (b) these difference have a considerable effect on their learning; (c) students' learning is heightened when teachers challenge them beyond their independent level; (d) learning is more effective when related to real-life scenarios; (e) student learning is enhanced by authentic learning opportunities; ( $f$ ) student learning is enhanced when they are respected and valued by their teachers, school, and community; and ( $g$ ) the ultimate goal of education is to recognize and promote the abilities of each student. Based on these assumptions, teachers can differentiate instruction by adjusting (a) content, (b) process, and/or (c) products based on students' readiness, interest, and learning profiles (Tomlinson, 1999; Rock et al., 2008).
\end{abstract}

7 5- Individualizing learning is likely most often used as it is a teacher-centered approach. Teachers look at assessment data to identify trends for the common needs of the group, either whole class or through small groups. For example, students working on research and writing may be identified into groups based on skill level for writing details, from a basic listing to using text evidence. When individualizing, teachers develop supportive designs, using student data. Students may be given choices, but they are generally not included in the drafting process. This teacher-centered approach is useful when the scaffolds and adjustments can be generalized based on students' shared common needs. Individualization and personalization are both good for meeting learner needs. While there may be arguments by proponents on both sides, what matters is differentiating for what students need to achieve. Analysis of these ideas can provide us a nuanced perspective that contributes to the search for improving student achievement. The best option will depend on the teacher's comfort zone when planning and how best students might respond. Individualizing is a common choice 
learning process based on the student's abilities and interests: Content; earning technology, and pace of learning (Rothstein, 2004).

\subsection{Contextual Teaching Approach}

The contextual teaching approach engages students in an active learning process, and it entails some teaching strategies: problem-based learning, cooperative learning, service-learning, work-based learning, project-based learning, and react strategies (Berns \& Erickson (2001). The contextual teaching approach's implementation involves REACT (relating, experiencing, applying, cooperating, and transferring) strategies used to establish their sense of interest, confidence, and need for understanding.

REACT strategies in contextual teaching approach can help students improve their learning (Crawford, 2001):

-Relating: Relating is the most powerful element in contextual teaching strategy. It also suggests that students' learning in the context of one's life experiences or preexisting knowledge (Crawford, 2001). In relating, teachers link a new concept to something completely unknown to students. Hadley, (2001). called this reaction "felt meaning." That reaction can be momentous, as when a student finds the solution to a problem, they have spent significant time and effort in solving it.

-Experiencing: In a contextual approach, one strategy relates to another. The previous statement indicates that relating connects new information to life experiences or prior knowledge that students bring to the classroom. Teachers can overcome this obstacle and help students construct new knowledge with hands-on experiences inside the classroom. This strategy is called experience. Students learn by exploring, discovering, and inventing (Crawford, 2001).

-Applying: Applying strategy can be defined as learning by putting the concepts to use (Crawford, 2001). Clearly, students can implement the concepts when they are engaged in hands-on problem-solving activities. Teachers can also motivate a need for understanding the concepts by assigning realistic and relevant exercises. Relating and experiencing are strategies for developing insight, felt meaning, and understanding. Applying is a contextual teaching and learning strategy that develops a more profound sense of meaning.

-Cooperating: Students cannot make significant progress in a class when they work individually. On the other hand, students working in small groups can handle that complex problem with little outside help (Pintrich \& Schunk, 1996). Teachers using student-led groups to complete exercises or hands-on activities use the strategy of cooperating. This strategy refers to learning in the context of sharing, responding, and communicating with other learners (Crawford, 2001). Most students feel less selfconscious and can ask questions without feeling embarrassed when working with peers in a small group discussion. Another fact of cooperative learning is that it can be counterproductive. For example, some students may not participate in the group processes at all, while others may dominate and the group members may refuse to accept or share responsibility for the group's work.

-Transferring: In traditional classroom, students' roles are to memorize the facts and practice the procedures by working skill drill exercises and word problems. In contrast, in a contextual or constructivist classroom, the teachers' role is expanded to include creating a variety of learning experiences with a focus on understanding rather than memorization (Crawford, 2001). Transferring is a teaching strategy that we define as using knowledge in a new context or novel situation-one that has not been covered in class. It suggests that students who learn with understanding can also learn to transfer knowledge (Bransford, Brown, \& Cocking, 1999).

According to Wandasari (2011), contextual Teaching and Learning (CTL) is a learning strategy that emphasizes the full process of student involvement in order to find the material learned and relate it to real life situations that encourage students to apply it in their lives. CTL is a grassroots initiative that has emerged from teachers' efforts to build upon situated-cognition research and integrate into one approach a number of validated strategies that are too often employed independently of one another (Glynn, 2004). Contextual learning is a learning concept whereby teachers present real-world situations into the classroom and encourage them to connect their knowledge and application in their lives as family and community members. Therefore, an individual's meaning and knowledge are outcome of one's own experiences. Without experiences the individual is empty (Sylker \& Kiyoshi, 2014).

Learning outcomes are expected to be more meaningful for students to solve problems, think critically, conduct observations, and draw conclusions in their long-term lives. In that context, students need to understand what learning means, the benefits,

by teachers because it seems quicker to manage and plan with only one person, the teacher. Arguably, individualization based on sound assessment results can be used for many day-to-day student needs. Personalization requires teachers to be willing to give up at least some of their control of the planning. 
what status they are, and how to achieve them. CTL motivates learners to take charge of their own learning and connect knowledge and its applications to the various contexts of their lives: as family members, as citizen, and as workers (Sears, 2003). Contextual is just a learning strategy. As with other learning strategies, the contextual is developed to learn goes more productive and meaningful. The contextual approach can be run without changing the curriculum and the existing order by involving the seven main components of effective learning: Constructivism, Questioning, Inquiry, Learning Community, Modeling, and Authentic Assessment. CTL learning strategy is an educational process that aims to help students see meaning in the academic material they learn by connecting academic subjects with the contents of daily life, that is with the context of personal, social and cultural life. Contextual learning is a learning model that provides facilities for student learning activities to find, process, and find learning experiences that are more concrete related to real life through student activities in trying, doing, and experiencing themselves. Incorporating the principals of contextual teaching helps promote authentic learning and increases students' success by making connections as they construct knowledge (Hudson \& Whisler, 2001). Contextual teaching and learning represent a concept that involves connecting the content, the student's learning, and the context in which the content will be used (Putnam \& Leach, 2005). ${ }^{8} \mathrm{CTL}$ strategy is an educational process that aims to help students see meaning in the academic material they learn by connecting academic subjects in the context of their daily lives, with the context of their personal, social and cultural circumstances. To achieve this goal, the system includes the following eight components: making meaningful connections, doing meaningful work, doing self-regulated learning, collaborating, critical and creative thinking, helping individuals to grow and develop, attaining high standards, and using authentic scoring (Mulyadin, 2010). Hudson, Whisler and Vesta (200)list that there are seven strategies in carrying out in implementing CTL learning, that is: -Problem-based Teaching. The educator raises the learner's problem to think critically in solving the problem. This problem will bring personal and social meaning to the students.

-Using diverse contexts. Educators make various contexts (school, family, community and so on) so that meaning (knowledge) is more qualified.

-Consider student diversity. Educators nurture individuals and believe that individual and social differences should be used as a driving force for mutual respect and tolerance for the realization of interpersonal skills.

-Empowering students to learn independently and every human being is a lifelong active learner.

-Learning through collaboration. Learners get- accustomed to learn from each other and from groups to share knowledge and determine the focus of learning.

-Use authentic scoring. Authentic assessment shows that learning has taken place in an integrated and contextual manner, and provides an opportunity for learners to move forward in accordance with their potential.

-Pursuing high standards. Schools determine graduation competencies from time to time are continuously improved.

The purpose of contextual learning is to equip students with knowledge and skills that are more realistic because the core of this learning is to bring things theoretical to practical. So that in the implementation of this method is cultivated theory that is learned applied in a real situation.

\section{Method}

The study followed the descriptive-analytical method.

\subsection{Reliability}

The reliability of the whole questionnaire can be estimated by using the formula:

$\mathrm{R}=1-\frac{6 \sum_{d} 2}{n\left(n^{2}-1\right)}$

${ }^{8}$ Contextual learning, then, engages students in meaningful, interactive, and collaborative activities that support them in becoming self-regulated learners. Additionally, these learning experiences foster interdependence among students and their learning groups. Complementary outcomes assessments for contextual student learning are authentic assessment strategies.Some examples of contextual teaching and learning are interdisciplinary activities across content areas, classrooms, and grade levels; or among students, classrooms, and communities. Problem-based learning strategies, for instance, can situate student learning in the context of students' communities. Many skills learned as parts of contextual learning activities are transferable skills, those that can be used not only for successful completion of a current project, but also in other content areas to prepare a student for success in later vocational endeavors. CTL is the way or the concept of teaching that helps teacher and students to relate subject matter to the real life situation and motivate students to connect and apply all aspect of learning into students' role in real life. When talking about context, most people said that context related to people's social life. In the classroom teaching, CTL means teacher should present the student real world inside the classroom. Beside that in teaching learning process there are also many teachers who still teach by using conventional learning. 
Where $R=$ reliability $\quad D=$ difference $N=$ number of individuals.

Table 1. The reliability of the Questionnaire.

\begin{tabular}{lllll}
\hline$X$ & $Y$ & $X Y$ & $D$ & $D^{2}$ \\
\hline 1 & 2 & 2 & 1 & 1 \\
3 & 4 & 12 & 1 & 1 \\
5 & 6 & 30 & 1 & 1 \\
7 & 8 & 56 & 1 & 1 \\
9 & 10 & 90 & 1 & 1 \\
11 & 12 & 132 & 1 & 1 \\
13 & 14 & 172 & 1 & 1 \\
15 & 16 & 240 & 1 & 1 \\
\hline
\end{tabular}

$\mathrm{R}_{1}-1=\frac{6 * 8}{50\left(50^{2}-1\right)}=1-\frac{48}{124950}=0,99$

The spearman formula was used to make the $\mathrm{CO}$ efficient of reliability for the whole unit=

$\underline{2 * \text { coefficientofreliabiltyofthefirsthalf }}$

1+coefficietofthereliabiltysecondhalf

$$
\mathrm{R}=2 * \frac{0,99}{1+0,99}=0,9
$$

The result obtained is 0,9 which means that the questionnaire is reliable and consistent.

0,95 where $\mathrm{V}=$ the validity, $\mathrm{R}=$ the reliability $=\sqrt{0,9}=\mathrm{V}=\sqrt{R}$

The procedure of data analysis 3.3

Statistical package for social sciences (SPSS) was used to analyze the data collected by reflecting the frequency and percentage, whereas tables and graphs were used to present the results.

\subsection{Validity}

In order to show the appropriateness and the effectiveness of the tool used for data collection in the present study, some experts were asked to check to what extent the items of the questionnaire were suitable in terms of instructions, the types of items and their suitability for the subjects, the style and the language used in the tools, the illegibility of the items and any other comments. The questionnaire was checked and examined by experts from the Department of English, Faculty of Education Hantoub, University of Gezira, before it was distributed for teachers to fill.

\subsection{Participant}

The sample selection was done randomly by taking 50 English teachers from the target population. They were chosen from King Khalid University to participate in this study. Their experiences ranged between (5 - 25) years. They were 24 males and 26 females.

\subsection{Data collection tool}

This study's selected tool is a questionnaire for 50 English teachers teaching English as an intensive course at KKU. The questionnaire was prepared and distributed to then; it was made up of 16 items. The items were arranged in the logical progression depending on the study's hypotheses; the data were calculated manually, then analyzed by the computer, with the program (SPSS) Statistical Package for Social Sciences. 


\section{Results}

With reference to Table 2, teacher responses to the customization and implementation of contextual teaching approach.

Table 1. Customization and implementation of contextual teaching approach.

\begin{tabular}{llllll}
\hline No & Items & Agree & & \multicolumn{2}{l}{ Disagree } \\
\cline { 3 - 5 } & & Frequency & $\%$ & Frequency & $\%$ \\
\hline 1. & $\begin{array}{l}\text { There is a considerable link between the progress } \\
\text { of Saudi students' level and implementation } \\
\text { customization in terms of needs, preferences and } \\
\text { learning styles }\end{array}$ & & $82 \%$ & 9 & $18 \%$ \\
2. $\quad \begin{array}{l}\text { Implementation of contextual teaching approach } \\
\text { in teaching English as an intensive course }\end{array}$ & 42 & $84 \%$ & 8 & $16 \%$ \\
3. & & & $12 \%$ \\
\hline & $\begin{array}{l}\text { Consideration of student's needs, preferences } \\
\text { and learning styles facilitate learning process }\end{array}$ & 44 & $88 \%$ & 6 & \\
\hline
\end{tabular}

From the above table, it is noticed that the implementation of customization and contextual teaching methods helps foster students' level $88 \%, 84 \%$, and $82 \%$ confirm the positive impact of customized instruction and syllabus. In addition, implementing a contextual teaching approach helps foster students' level and simulates the sense of hard work and feeling of belonging.

Table 3 Personification, individualization and differentiation approach

\begin{tabular}{|c|c|c|c|c|c|}
\hline \multirow[t]{2}{*}{ No } & \multirow[t]{2}{*}{ Items } & \multicolumn{2}{|l|}{ Agree } & \multicolumn{2}{|l|}{ Disagree } \\
\hline & & Frequency & $\%$ & Frequency & $\%$ \\
\hline 1 & $\begin{array}{l}\text { Students' needs must be considered in } \\
\text { instruction and syllabus. }\end{array}$ & 44 & $88 \%$ & 6 & $12 \%$ \\
\hline 2. & $\begin{array}{l}\text { Students' preferences must be considered in the } \\
\text { textbooks. }\end{array}$ & 44 & $88 \%$ & 6 & $12 \%$ \\
\hline 3. & $\begin{array}{l}\text { Students' learning styles and aptitude must be } \\
\text { regarded in the instruction and textbooks. }\end{array}$ & 48 & $96 \%$ & 2 & $4 \%$ \\
\hline 4. & $\begin{array}{l}\text { Students' tips and opinions toward tasks, } \\
\text { activities and exercises must be considered in } \\
\text { the instructional process. }\end{array}$ & 47 & $94 \%$ & 3 & $6 \%$ \\
\hline 5. & $\begin{array}{l}\text { English learnt in the class must be correlated to } \\
\text { real social life setting }\end{array}$ & 45 & $93 \%$ & 5 & $10 \%$ \\
\hline
\end{tabular}

It can be seen from table 3,96\% of the participants suggest that personification, individualization and differentiation must be considered in instructional process and syllabus. Moreover, 92\% agree with the importance of considering learners' needs in instruction and syllabus. $92 \%$ of the teachers agree on considering learners' preferences in text book and exercises.90\% of them agree on correlate English course with the real social setting.

\section{Discussion and Conclusions}

From the above results, it is noticed that the implementation of customization from consideration of the learners' needs, preferences, learning styles, and opinions helps grasp students' attention and fosters their levels. It is also noticed that the majority of teachers support the implementation of contextual teaching approach in English class. Furthermore, it is noticed that the implementation of customization in the teaching process makes learning English much easier in terms of students' 
engagement and comprehension and the implementation of a contextual teaching approach in teaching English as an intensive course program fosters learning English.

This result indicates that customization and contextual teaching approach help foster students' English proficiency and satisfy their learning goals. To sum up, the researchers recommend the following:

a. Teaching English should be based on students' needs, preferences and learning styles.

b. English text books should be designed with pedagogic regard to the learners' aptitude, social life setting and cultural background.

c. Teaching English should be based on learner centeredness with maximization of student talking time.

d. English text book for Saudi students studying English as an intensive course should be personified, differentiated, and individualised to adapt students' needs.

e. English teachers should link English class with real social life setting to maintain real interpersonal practical communication.

f. Customized instruction and syllabus grasps students' attention and satisfies their needs and preferences.

\section{References}

[1] Bray, B., \& McClaskey, K. (2014). Make learning personal: The what, who, wow, where, and why. Corwin Press.

[2] Berns, R. G., \& Erickson, P. M. (2001). Contextual teaching and learning: Preparing students for the new economy (Vol. 5). Columbus, OH: National Dissemination Center for Career and Technical Education.

[3] Crawford, M. L. (2001). Teaching contextually. Research, Rationale, and Techniques for Improving Student Motivation and Achievement in Mathematics and Science. Texas: Cord.

[4] Hadley, O. A. (2001). Teaching language in context (3rd Ed.). Boston: Heinle \& Heinle., NJ:Prentice Hall.

[5] Hudson, C. C., \& Whisler, V. R. (2001). Contextual teaching and learning for practitioners. Journal of.

[6] Martinez, M. (1999). Mass customization: A paradigm shift for the 21st century. ASTD Technical Training Magazine, 10(4), $24-26$.

[7] -Mulyadin, T. (2010). The use of contextualization in improving students'

[8] reading skill in descriptive text. [Undergraduate Paper of UPI]. UPI Bandung: Unpublished.

[9] Pipkin, C. (2015). Three Key Policy Changes to Support Student Centered Learning. EdSurge

[10] Powell, W., \& Kusuma-Powell, O. (2011). How to teach now: Five keys to personalized learning in the global classroom. Ascd.

[11] Rothstein, R. (2004). Class and schools: Using social, economic, and educational reform to close the black white achievement gap. New York: Teachers College Press.

[12] Sears, S. J. (2002). Contextual teaching and learning: A primer for effective instruction. Phi Delta Kappa International.

[13] Tomlinson, C. A. (2001). How to differentiate instruction in mixed-ability classrooms. ASCD.

[14] Tseng, M. M., \& Jiao, J. (2001). Mass customization. Handbook of industrial engineering, 3, 684-709.

[15] Zimmerman, B.J. (1990). Self-regulated learning and academic achievement: Anoverview. Educational Psychologist, 25(1). 3-17.

[16] Wandasari, T. (2011). Using contextual teaching and learning (CTL) in improving students' reading skill in procedural text. Undergraduate Paper of UPI. UPI Bandung: Unpublished.

[17] Zmuda, A., Curtis, G., \& Ullman, D. (2015). Learning personalized: The evolution of the contemporary classroom. John Wiley \& Sons. 